\title{
COMMENT
}

\section{TREATIES AND THE SUPREME COURT}

\author{
JAMES J. LENOIR*
}

$7 \mathrm{HE}$ recent case of Factor v. Laubenheimer ${ }^{\mathrm{r}}$ is apparently a dénouement 1 to the picturesque career of John (Jake, the Barber) Factor which the American public has followed with some interest for the past two years. Charged by the British government with having received "from Broad Street, Limited, large sums of money aggregating $£_{45} 8,000$, knowing the same to have been fraudulently obtained,"2 Factor strenuously resisted extradition to Great Britain on the ground that the offense with which he was charged was not a crime in the place where he had taken refuge (Illinois). His counsel contended that an extraditable offense must be a crime both in the demanding country and in the place where the fugitive is found, and that the applicable treaty provisions, interpreted in the light of that principle, excluded his extradition.

The question before the Court, therefore, by its own statement was "one of the construction of the provisions of the applicable treaties in accordance with the principles governing the interpretation of international agreements." 3

What are these principles to which the Court refers? Are they principles of customary or conventional international law, or are they self-imposed standards of construction? If they are self-imposed, have they been established in a series of precedents which has made them binding in future cases?

Before attempting to answer these questions, it seems important to make a general survey of the decisons and opinions of the Court which involve treaties. It is difficult to separate questions of treaty construction from questions of the nature and legal position of treaties, because these two phases of treaty law are closely linked together and are more or less interdependent. Therefore, we shall first make a general study of the

* Assistant in Political Science, University of Hllinois.

I Factor v. Laubenheimer, 54 Sup. Ct. I9r, 206 (I933).

${ }^{2}$ Laubenheimer v. Factor, 6I F. (2d) 626, 634 (C.C.A. $7^{\text {th } 1932) . ~}$

${ }^{3}$ Supra note $\mathrm{x}, \mathrm{r} 93$. 
treaty cases, to be concluded by an examination of the principles of interpretation which the Court has applied.

There have been a great many such cases before the Court, 4 extending, in point of time, from Ware v. Hylton,,$^{5}$ the first important case in which rights derived from a treaty came up for adjudication, to the recent decision of Factor v. Laubenheimer. In analyzing these cases the first question that confronts us is: what is a "treaty"? Do the definitions of treaties found in the cases under discussion conform to the definitions commonly accepted by writers on international law? How has the Supreme Court defined treaties? Is there an acceptable definition of the term ${ }^{36}$ In a study of the cases one finds it difficult to discover an acceptable or a final definition. There has been little disposition to define a treaty in positive terms, and the few definitions that are found apply mainly to the special facts of the particular case. To protect its freedom of decision in future cases the Court has hesitated to adopt any concise definition. In some of the earlier cases one may find some attempts at definition, but if these attempts are subjected to a critical analysis they will be found lacking in certain essential respects. Later opinions have, for the most part, avoided any attempt at careful definition.

In some later cases the Court has, however, concerned itself with the meaning of the term "treaty" relative to the facts in the particular case. Thus, in Tucker v. Alexandroff, Justice Brown asserted that treaties are "solemn engagements entered into between independent nations for the common advancement of their interests and the interests of civilization." Chief Justice Taney said that a treaty, in so far as the courts were concerned, was a law made by the proper "authority." 8 Justice Field declared that a treaty was primarily a contract between two or more independent nations, ${ }^{9}$ a view practically the same as that expressed by Justice Brown

4 The first case which in any manner dealt with treaties was Glass v. Sloop Betsey, 3 Dall. (U.S.) 6, I L.Ed. 485 (I 794). In this case the court merely commented on treaties.

5 Ware v. Hylton, 3 Dall. (U.S.) x99, x L.Ed. 568 ( $(796)$.

6 "A treaty is primarily a compact between independent nations. It depends for the enforcement of its provisions on the interest and the honor of the governments which are parties to it." Edye v. Robertson, I 12 U.S. $580,598,5$ Sup. Ct. 247,28 L.Ed. 798 (1884). Cf. the definition as found in notes compiled by Devlin, Treaty Power (xgo8), 3-4, $\$ 2$. See also the definition given by Taney C. J., Holmes v. Jennison, 14 Pet. (U.S.) 540, 571, 10 L.Ed. 579 (I840); Iredell, J., Ware v. Hylton, 3 Dall. (U.S.) I99, 272, I L.Ed. 568 (r796); and Thompson, J., dissenting in Cherokee Nation v. Georgia, 5 Pet. (U.S.) I, 60, 8 L.Ed. 25 (I83I).

7 Tucker v. Alexandroff, 183 U.S. 424, 437, 22 Sup. Ct. I95, 46 L.Ed. 264 (I902).

${ }^{8}$ Doe v. Braden, 16 How. (U.S.) 635,657 , I4 L.Ed. Io9o (I853).

9 Whitney v. Robertson, I 24 U.S. 190, 194, 8 Sup. Ct. 756, 3 r L.Ed. 386 (I888). Cf. also Geofroy v. Riggs, I33 U.S. 258, 27 , ro Sup. Ct. 295, 33 L.Ed. 642 (I89o); and Chew Heong v. United States, I I 2 U.S. 536, 562, 5 Sup. Ct. 255, 28 L.Ed. 770 (I884). 
in the Alexandroff case. Chief Justice White adopted the same definition in Rainey v. United States, ${ }^{10}$ and it has been repeated in most of the remaining decisions in which the Court found occasion to define a treaty. Of course, it would be difficult to criticize the broad definition of Chief Justice Taney, for in so far as the Court is concerned a treaty is a law, to which the Court at present refers by citing the Statutes of the United States."

Whatever definition the Supreme Court may adopt for the term "treaty" the fact remains that certain definite constitutional requirements must be fulfilled before there can be a treaty. Yet in recent practice the Supreme Court has accepted treaties as they are proclaimed; that is to say, whatever is designated as a treaty by the political departments in which are vested the treaty-making power will be so considered by the Court. Although, as has been pointed out, it has not been the tendency of the Court to accept or lay down general definitions, perhaps one may venture a definition from the cases taken as a whole. In general, the Court has seemed to adhere to the view that a treaty under the municipal law of the United States is a compact or an agreement existing between the United States and certain other independent or semi-independent nations, conforming to the constitutional requirements and proclaimed as part of the law of the United States. ${ }^{x 2}$ This is a sufficient definition of a treaty for the purpose of this study. An essential element in the definition, according to

so Rainey v. United States, 232 U.S. 3ro, 316, 34 Sup. Ct. 429, 58 L.Ed. $61_{7}$ (I9I4).

xx Justice Iredell, Ware v. Hylton, 3 Dall. (U.S.) I99, 272, I L.Ed. 568 ( ${ }_{79} 96$ ) said in referring to treaties, "Laws are always seen, and through that medium people know what they have to do. Treaties are not always seen. Some articles (being what are called secret articles) the people never see. The present Constitution of the United States affords the first instance of any government, which, by saying, treaties should be the supreme law of the land, made it indispensable that they should be published for the information of all."

${ }^{12}$ According to the doctrine and practice of many countries treaties do not become binding upon the public authorities or upon private individuals nor are they enforceable by the courts until they have been incorporated or "transformed" into municipal law by some form of executive or legislative action, and thus made a part of the law of the land. Where this doctrine and practice prevail it is admitted, however, that incorporation or transformation is not essential to the international obligatory force of the treaty as a compact between the parties. The-latter results from the principle of pacta sunt servanda, and the treaty becomes binding as between the parties from the moment it takes effect, which is usually upon the exchange or deposit of ratification or at some ulterior date fixed by the treaty itself. But its intra-territorial operation does not begin until it has been incorporated or transformed into the body of municipal law. Until then the treaty is not binding upon private individuals or the public authorities; nationals cannot claim the benefit of its stipulations, and the courts will not apply its provisions in cases which come before them and in which its stipulations are invoked by litigants. See the instances cited by Grimm, I4 Zeitsclirift fiir Völkerrecht, 477 ff. J. W. Garner, Preliminary Draft of Articles of a Convention on Treaties, for the Harvard Research in International Law. 
Haver v. Yaker, ${ }^{x 3}$ is the proclamation by the President. ${ }^{\mathrm{x}} 4$ Perhaps the reasoning and the holding in Haver v. Yaker would not withstand a critical analysis. ${ }^{15}$ However, in practice the Supreme Court accepts as the authentic text of treaties that found in the proclamation published with the statutes of the United States; ${ }^{16}$ and does not refer to the treaty series of the State Department. Private rights do not arise from a treaty until it has the force of law; and proclamation is considered an essential element which makes the treaty a part of the municipal law. ${ }^{17}$

The case referred to above, Haver v. Yaker, ${ }^{18}$ is illustrative of the point as to when treaties become effective. The facts in this case were as follows: Peter Yaker, a Swiss citizen, migrated to Kentucky, where he became a naturalized citizen of the United States. In July, I853, he died intestate, leaving a widow, and certain Swiss relatives. His estate was comprised of real and personal property of considerable value. The Swiss relatives laid claim to all of the property, but the courts of Kentucky held that they had a right only to the personal, and not to the real, property. The case came up on appeal to the Supreme Court as to the ownership of the real property. By the common law, which was in force in Kentucky, aliens are incapable of inheriting lands or taking them by descent, so it followed that the plaintiffs, aliens, could not succeed in the suit, unless they had rights protected by a law which was paramount to the law of the state. They claimed that the treaty signed in $185^{\circ}$ between the United States and Switzerland was such a law.

There were two treaties covering the question in the case, but according to the first one, of May, I848, the Swiss relatives would have had to dispose of the property within three years after inheriting it. Since the suit was brought several years after Peter Yaker's death, their rights under this treaty had lapsed and they based their claim upon a second treaty

${ }_{3}$ Haver v. Yaker, 9 Wall. (U.S.) 32, 35, I9 I.Ed. 57 ( 1869 ).

${ }^{14}$ As to the necessity of Proclamation see Wright, Control of American Foreign Relations (1922), 255; Crandall, Treaties, Their Making and Enforcement (2d ed. I9r6), 345; 2 Butler, Treaty Making Power of the United States (I9O2), I27; Hershey, Essentials of International Law (rgI2), 438, n. I 5; supra note II. Whether the courts would refuse to apply a treaty which had not been thus proclaimed is not certain. Triepel (I Acad. de Droit Int., Recueil des Cours [r923], 9I) thinks they would not and that appears to be the view of the American authorities just cited.

${ }^{15}$ Cf. criticism of the reasoning in this case, Phillipson, Termination of War and Treaties of Peace (rgr6), 195-197.

${ }^{16}$ In the United States treaties are put into effect by public proclamation of the President, and the text of the treaty is thereafter published in the Statutes at Large of the United States. The purpose of proclamation is to inform the people of the country of the terms of the treaty, and its effect is to make the treaty a part of the supreme law of the land. Garner, supra note 12.

${ }^{17}$ Ibid.

${ }^{8}$ Supra note 13 . 
signed in November, 1850 , and ratified in November, 1855 . It became important to discover at what date this treaty came into force in so far as private rights were concerned. The Court, speaking through Justice Davis, held that it was undoubtedly true, as a principle of law, that as respects rights of either government under it, "a treaty is considered as concluded and binding from the date of its signature." In this case the Court reasoned that the international obligatory force of the treaty dated from signature by the parties. But the Court claimed that a different rule prevails where the treaty operates on individual rights. "In so far as it affects them, it is not considered as concluded until there is an exchange of ratification, and this we understood to have been decided by this court, in Arredondo's case." The Court then asserted that the reason for this rule was:

In this country, a treaty is something more than a contract, for the Federal Constitution declares it to be the law of the land. If so, before it can become a law, the Senate, in whom rests the authority to ratify it, must agree to it. But the Senate are not required to adopt or reject it as a whole, but may modify or amend it, as was done with the treaty under consideration. As the individual citizen, on whose rights of property it operates, has no means of knowing anything of it while before the Senate, it would be wrong in principle to hold him bound by it, as the law of the land, until it was ratified and proclained. ${ }^{19}$

In further consideration of the nature of treaties it is interesting to note the extent to which the Court has compared them with contracts in private law. ${ }^{20}$ Perhaps international law has not yet developed to such a point that one can say that treaties are fully as binding as contracts in private law, yet the Supreme Court has, with uniform consistency, referred to treaties as being by their nature contracts between nations. Moreover if one compares the term "treaty" as it is commonly accepted in international law and in the definition of publicists with the definition of the term "contract," suggested by the Restatement of the Law of Contracts, he will not find any substantial differences between the two. ${ }^{2 r}$

19 Italics supplied. See note Ir supra; 6 Ops. Atty. Gen. 748-750 ( 8854 ); Crandall, supra note 14, 346, n. 9; Wright, Control of American Foreign Relations (r922), 255-256.

${ }^{20} \mathrm{Cf}$. the comment in Haver v. Yaker, quoted above.

${ }_{21}$ "A contract is a promise or a set of promises for the breach of which the law gives a remedy, or the performance of which the law in some way recognizes as a duty." Restatement (r932), I: "In a bilateral contract, on the other hand, as there are contractual promises on both sides, the contract is properly called bilateral," ibid., rr. Anson, Contracts (Corbin's 3 d Amer. ed. I9I9), $\mathrm{I}_{3}$, "[A contract] is an agreement enforceable at law, made between two or more persons, by which rights are acquired by one or more to acts or forbearances on the part of the other or others."

"As the term is used in this convention, a 'treaty' is a formal instrument by which an obligation is assumed by one or more states vis-d-vis one or more other states, for the breach of which 
Various members of the Supreme Court have compared contracts with treaties; for example, in Whitney v. Robertson, Justice Field said, "A treaty is primarily a contract between two or more independent nations, and is so regarded by writers on public law." ${ }_{22}$ Justice Baldwin stated that a "treaty is in its nature a contract between two nations," ${ }^{23}$ and Chief Justice Taft spoke of the parties to the treaty as "contracting." 24 Indeed, such expressions are so common that they are found in nearly all of the cases decided by the Court. This view, that treaties are contracts, probably indicates that the Supreme Court laid greater emphasis upon the contractual nature of treaties than was commonly found in the practice of nations or than was accepted by publicists and writers on international law..$^{25}$

In spite of the fact, however, that the Supreme Court draws an analogy between treaties and private law contracts, it must not be concluded that the Court considers them as deserving identical treatment. Although as a general policy the Court regards treaties as being in the nature of or somewhat similar to contracts, it does not consider all treaties that are brought before it in the same light as it would consider contracts between private individuals. The differences recognized by publicists between treaties and contracts are apparent to the Supreme Court. ${ }^{26}$ International law is in a stage of development; private law possesses a degree of certainty not found in international law; therefore, those treaty provisions that are brought before the Court are regarded as being in the nature of contracts. ${ }^{27}$

If we accept the definition of treaties based upon the rulings of the Court the question naturally arises as to the position of treaties in the system of law in the United States. The Constitution declares that "all treaties made, or which shall be made, under the authority of the United

the party committing it would be responsible under international law." Garner, supra note I2. Renault, Introduction à l'étude du Droit International, 33-34, "... tout accord intervenu entre deux ou plusieurs états, quelque puisse être son objet, quel que soit le nom qu'on lui donne et de quelque manière qu'il soit constate."

${ }_{22}$ Whitney v. Robertson, I24 U.S. I9o, 194, 8 Sup. Ct. 456, 3 I L.Ed. 386 (r888); see Geofroy v. Riggs, 133 U.S. 258 , 271 , Io Sup. Ct. 295,33 L.Ed. 642 (189o).

${ }_{23}$ United States v. Arredondo, 6 Pet. (U.S.) 69I, 735, 8 L.Ed. 547 (I832).

${ }_{24}^{4}$ Ford v. United States, 273 U.S. 593, 6I8, 47 Sup. Ct. 53r, 7 r L.Ed. 793 (1927).

${ }^{25} \mathrm{Cf}$. Brierly, The Obsolescence of Treaties, $\mathrm{x} x$ Transactions of the Grotius Society, $\mathrm{II} \mathrm{ff}$. (Ig26).

${ }^{26}$ Cf. Holland, Jurisprudence ( 13 th ed. I924), 402; Lauterpacht, Private Law Sources and

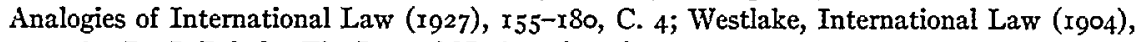
279-282, Pt. I; Brierly, The Law of Nations (1928), I65-I66.

${ }_{77}^{27}$ The analogy is apparent, yet the Court has jurisdiction over contracts in private law. It has no control over the other party to the treaty. 
States, shall be the supreme Law of the Land; and the Judges in every State shall be bound thereby, anything in the Constitution or Laws of any State to the contrary notwithstanding." ${ }_{28}$ When does an agreement become a treaty within the constitutional sense and thus binding on the Court? ${ }^{29}$ There are certain definite requirements made by the Constitution. In Article II it is provided that the President shall have the power, "by and with the advice and consent of the Senate, to make Treaties, provided two-thirds of the Senators present concur." 30 If this consent is secured the President may then ratify and proclaim the treaty whereupon the text is published in the Statutes at Large of the United States. The Court has always taken it as a matter of course that the political departments have acted in a constitutional manner in making treaties; that is, the Court has never held a treaty invalid on the ground that the procedure prescribed in the Constitution had not been followed, although it might conceivably do so. ${ }^{3 \mathrm{I}}$

The Supreme Court, in a number of cases, has examined certain facts as to the negotiation, signing, confirmation, ratification, or proclamation of a treaty; $;^{32}$ not, however, for the purpose of passing upon the validity of the treaty, but for the determination of certain private rights which were involved. Further discussion of these points will follow when the subject of the construction of treaties is considered.

The Constitution, as has been stated above, makes treaties a part of the supreme law of the land. They are thus to be regarded as law and the Supreme Court considers itself just as much bound by a treaty as by any law enacted by the legislative department of the government and signed by the President. But does the Court regard an executive agreement as having the force of a treaty? ${ }^{33}$ This form of an international agreement

${ }^{28}$ Art. VI, par. 2.

29 It would seem, according to Haver v. Yaker, supra note I3, and Altman \& Co. v. United States, 224 U.S. 583,32 Sup. Ct. 593, 56 L.Ed. 894 (1912), to be after the proclamation. See note II supra.

${ }^{30}$ Art. II, § 2, par. 2.

${ }_{35} 2$ Butler, supra note $14,363-364, \S 461$; American Society of International Law, Proceedings (I929), $x 79$.

32 United States v. Arredonjo, supra note 23, and cases arising from the treaty of $18 \mathrm{rg}$ with Spain. See United States v. Reynes, 9 How. (U.S.) 127, 13 L.Ed. 74 (I850); Davis v. Police Jury, 9 How. (U.S.) 280, $x_{3}$ L.Ed. I38 (1850).

${ }_{33}$ The courts have held that postal conventions concluded by the Postmaster General under the authority of an Act of Congress and ratified by the President without advice and consent of the Senate are not "treaties" in the sense of the Constitution and municipal law of the United States. Four Packages of Cut Diamonds v. United States, 256 Fed. 305 (C.C.A. 2d I9r9). The same view appears to have been taken by a Pennsylvania court in regard to protocols not ratified with the advice and consent of the Senate. MicCall's Estate, $28 \mathrm{~Pa}$. Dist. Ct. 433, 448 ( $(919)$. 
may be consummated with or without the authority of Congress. ${ }^{34}$ Yet the Supreme Court has found a definite distinction between this form of an agreement and a treaty as envisaged by the Constitution. ${ }^{35}$ Justice Day, speaking for the Court, said:

While it may be true that this commercial agreement, made under authority of the Tariff Act of $\mathrm{x} 897$, sec. 3 , was not a treaty possessing the dignity of one requiring ratification by the Senate of the United States, it was an international compact, negotiated between the representatives of two sovereign nations and made in the name and on behalf of the contracting countries, and dealing with important commercial relations between the two countries, and was proclaimed by the President. If not technically a treaty requiring ratification, nevertheless it was a compact authorized by the Congress of the United States, negotiated and proclaimed under the authority of its President. We think such a compact is a treaty under the Circuit Court of Appeals Act, and, where its construction is directly involved, as it is here, there is a right of review by direct appeal to this court..$^{36}$

If it is to be accepted as conclusive that treaties are part of the supreme law of the United States, are there any limitations upon the treaty-making power? It is the writer's view that the treaty-making power of the United States is limited only by the Constitution. ${ }^{37}$ The Supreme Court has, in a number of cases, also expressed the view that the Constitution is a limitation on the exercise of this power, but without commenting on whether this was the sole limitation. ${ }^{38}$ On occasion, the Court has expressed the

34 Cf. Moore, John Bassett, Treaties and Executive Agreements, 20 Pol. Sci. Quar. 385-420 (1905). He remarks that while in diplomatic literature the terms "treaty," "convention," and "protocol" are all applied more or less indiscriminately to international agreements, in the jurisprudence of the United States, the term "treaty" is properly to be limited, although the Federal Statutes and Courts do not always so confine it, to agreements approved by the Senate.

${ }^{35}$ Altman \& Co. v. United States, 224 U.S. 583, 601, 32 Sup. Ct. 593, 56 L.Ed. 894 (rgr2).

${ }^{36}$ Ibid., 6or.

37 See 2 Story, Commentaries on the Constitution of the United States (Cooley's 4 th ed. I873), 325-326, § I508. Cf. G. G. Wilson, International Law and the Constitution of the United States, $x_{3}$ Boston Univ. I. Rev. 250 (I933). He claims, "The limitations which stay the treaty-making power of the President would be that such an agreement must not be prohibited by the Constitution and must not be contrary to international law." Also see 2 Butler, supra note I4, $35 \circ \mathrm{ff}$; and American Society International Law, Proceedings (I929), I $7^{6-196 .}$

${ }^{38}$ Field, J., speaking for the Court in Geofroy v. Riggs, $x 33$ U.S. 258, 266-267, ro Sup. Ct. 295, 33 L.Ed. 642 (I890), said: "That the treaty power of the United States extends to all proper subjects of negotiation between our government and the governments of other nations, is clear. . . . The treaty power, as expressed in the Constitution, is in terms unlimited except by those restraints which are found in that instrument against the action of the government or of its departments, and those arising from the nature of the government itself and of that of the States. It would not be contended that it extends so far as to authorize what the Constitution forbids, or a change in the character of the government or in that of one of the States, or a cession of any portion of the territory of the latter without its consent. Fort Leavenworth Railroad Co. v. Lowe, II4 U.S. 525, 54I. But with these exceptions, it is not perceived that there is any limit to the questions which can be adjusted touching any matter which is properly the subject of negotiation with a foreign country. Ware v. Hylton, 3 Dall. I99; Chirac v. 
view that the treaty-making power is not directly limited by the Constitution; for example, this was indicated in certain dicta in Downes v. Bidwell..$^{39}$ This may be considered as an academic question, however, for the Supreme Court has never held a treaty to be void because of being contrary to the Constitution. Yet it seems clear that a treaty may deal with matters beyond the enumerated powers of Congress; and thus, under the "necessary and proper clause," may serve as a basis for extending the powers of Congress. ${ }^{40}$

Missouri v. Holland is a case illustrating the extent to which the treaty-. power can be carried, for here a treaty was upheld which apparently conflicted with a constitutional provision. ${ }^{4 \mathrm{I}}$ In this case the State of Missouri brought suit to prevent a United States game warden from enforcing the Migratory Bird Treaty Act..$^{42}$ On December 8, I9I6, the President had proclaimed a treaty with Great Britain for the protection of birds migrating between the United States and Canada. ${ }^{43}$ On July 3, I9I8, Congress enacted the above mentioned law as an "Act To Give Effect to the Convention." Acts of Congress of similar nature, enacted before the treaty was concluded, had been declared invalid in two federal court cases, ${ }^{44}$ and in this case the Court had to decide whether the treaty and statute were void as an interference with the rights reserved to the states.

The Court made several important comments before it actually decided the question at issue. It claimed that if the treaty were valid, then there would be no dispute about the validity of the statute, for under Article I, Section 8 of the Constitution, it would be justifiable as a necessary and proper means to execute the powers of the government. The Court found, however, that the treaty did not contravene any prohibitory words found in the Constitution, so that the only question was whether it was

Chirac, 2 Wheat. 259; Hauenstein v. Lynham, too U.S. 483 ; 8 Opinions Attys. Gen. 4x 7 ; The People v. Gerke, 5 California, 38r." Charles Henry Butler maintains that the treaty-power extends even farther than Justice Field's dictum would have it extend. American Society International Law, Proceedings (r929), I8r. Cf. In re Ross, I 40 U.S. 453, 463, II Sup. Ct. 897 , 35 L.Ed. $5^{8 \mathrm{I}}(\mathrm{I} 8 \mathrm{gI})$.

${ }^{39}$ See White, J., concurring, Downes v. Bidwell, 182 U.S. 244, 317-3x8, 21 Sup. Ct. 770, 45 L.Ed. 1088 ( $x_{9 \circ 1}$ ). Cf. Wright, Constitutionality of Treaties, $x_{3}$ Am. Jour. Int. L. 242 (I9rg); Anderson, Extent and Limitation of the Treaty-Making Power under the Constitution, I Am. Jour. Int. L. 636-670 (I907).

40 Missouri v. Holland, 252 U.S. 4I6, 40 Sup. Ct. 382, 64 L.Ed. 64I (I920).

${ }_{41}$ See the comment of Powell, 35 Pol. Sci. Quar. 416-4r7 (r920); also the discussion concerning the case by Kingsbury, American Society International Law, Proceedings, I84 (I929).

${ }_{42} 40$ Stat. 755 (I9r8), I6 U.S.C.A. \$703. $\quad{ }^{43} 39$ Stat. I702 (I9r6), I6 U.S.C.A. § 703.

44 United States v. Shauver, $2{ }_{4}$ Fed. I54, I6r (D.C.E.D. Ark. rgr4); United States v. McCullagh, 22r Fed. 288, 296 (D.C. Kan. 1915). 
"forbidden by some invisible radiation from the general terms of the Ioth Amendment." In answering this question the Court declared that the power of the National government extended beyond that of the states and if the National government deemed it necessary to enter into a treaty to protect a food supply of this nature, there was nothing in the Constitution to prohibit it from doing so. It may be said, therefore, that in this opinion Justice Holmes laid it down as a rule that a treaty within the scope of the treaty-making power is supreme.

In this connection one may note the admirable summary made by the present Chief Justice of the Supreme Court with respect to the relation between treaties, the treaty-making power, and the Constitution. In I929, he said:

I think that it is perfectly idle to consider that the Supreme Court would ever hold that any treaty made in a constitutional manner in relation to the external concerns of the nation is beyond the power of the sovereignty of the United States or invalid under the Constitution of the United States where no express prohibition of the Constitution has been violated. ... . If we take the Constitution to mean what it says, it gives in terms to the United States the power to make treaties. It is a power that has no explicit limitation attached to it, and so far there has been no disposition to find in anything relating to the external concerns of the nation a limitation to be implied.45

With respect to the constitutional position of treaties, it is a rule of law that when a conflict between a treaty and an act of Congress occurs the latter will prevail if it is subsequent to the treaty. ${ }^{46}$ When either statutes or treaties expressly conflict with the Constitution, which is supreme, it is conceded that the constitutional provisions prevail. The Court has said, in giving effect to acts of Congress which were in conflict with treaties, that its action was in no way intended to relieve the United States of its international responsibility as a party to the treaty, and this would undoubtedly also be true in case the Court ever overruled a treaty provision which conflicted with the Constitution. ${ }^{47}$

${ }_{45} \mathrm{Mr}$. Hughes was a member of the Permanent Court of International Justice when he made this statement. American Society International Law, Proceedings (rg29), rg6.

${ }^{6}$ The Cherokee Tobacco, II Wall. (U.S.) 6I6, 624, 20 L.Ed. 227 (1870); Head Money Cases, I I 2 U.S. 580,5 Sup. Ct. 247,28 L.Ed. 798 (r884); Whitney v. Robertson, I 24 U.S. I9o, 8 Sup. Ct. $456,3^{\text {I L.Ed. } 386 \text { ( }} 8888$ ).

47 Botiller v. Dominguez, I30 U.S. $238,247,9$ Sup. Ct. $525,3_{2}$ L.Ed. 926 ( 1889 ), Justice Miller said that the court was bound "to follow the statutory enactment of its own government. If the treaty was violated by this general statute enacted for the purpose of ascertaining the validity of claims derived from the Mexican government, it was a matter of international concern, which the two states must determine by treaty, or by such other means as enables one state to enforce upon another the obligations of a treaty. This court, in a class of cases like the present, has no power to set itself up as the instrumentality for enforcing the provisions of a treaty with a foreign nation which the government of the United States, as a sovereign power, chooses to disregard." 
A number of cases have been decided in which there was a conflict between a treaty and an act of Congress..$^{48}$ The Court, on several occasions, has declared that it would so construe a statute and a treaty as to give meaning to both if this was possible. In all cases the Supreme Court has clearly supported the statute when it was later in date than the treaty;49 but it is doubtful whether it will as readily support a treaty in conflict with an anterior statute. ${ }^{50}$ In this latter group of cases it appears that the Court has resorted to every possible system of reasoning to reconcile the statute and the treaty. In Cook $\%$. United States ${ }^{5 \mathrm{x}}$ the Court upheld the conflicting posterior treaty, but this seems to be an exception to the rule.

Although the Court may, in some instances, have supported or interpreted acts of Congress at the expense of treaties it has observed the constitutional provisions in regard to the supremacy of treaties over state laws. Ware v. Hylton, ${ }^{52}$ the first important case concerned with treaties, dealt with this point. In that decision the Court upheld rights derived from a treaty even though the treaty conflicted with the law of the State of Virginia.

The consistent application of the above principle has resulted in a narrow and strict interpretation of the state law and in decisions favorable to the international agreement. Nearly all of these cases reached the Supreme Court on appeal from the highest state courts, which had, in most instances, rendered decisions favorable to state statutes by either reconciling them with existing treaties or by supporting the state statutes when

${ }^{8}$ The Cherokee Tobacco, II Wall. (U.S.) 616, 20 L.Ed. 227 (x870); Chae Chan Ping v. United States, I30 U.S. 58I, 9 Sup. Ct. 623, 32 L.Ed. ro68 (r889); Head Money Cases, supra note 46; Whitney v. Robertson, supra note 46; Hijo v. United States, I94 U.S. 3I5, 324, 24 Sup. Ct. 727, 48 L.Ed. 994 (I904).

${ }^{49}$ Ibid. The view of the Court is that, since by the terms of Article VI of the Constitution acts of Congress and treaties are declared to be the supreme law of the land, they are on a footing of equality, neither being juridically superior to the other, and consequently the latest treaty or statute, is binding on the courts and must be applied as the law of the land. 2 Butler, supra note $\mathrm{x4}, \S \S 367 \mathrm{ff}$., and Crandall, supra note $\mathrm{x4}$, x6r.

${ }^{\text {so }} 2$ Butler, supra note $\mathrm{I}_{4}, 84-86$, says that, "As a general conclusion, it can be stated that although treaties and statutes have been held by the courts to be on the same plane as the supreme law of the land, and that while treaties can suprsede prior acts of Congress; and acts of Congress can supersede prior treaties, as was held in a case decided by Justice Swayne in I870 (The Cherokee Tobacco, Ir Wall. 6I6), it more often happens that the statute abrogates, and supersedes, the treaty, than that the treaty abrogates, and supersedes, the statute; not because a statute is a higher order of law than a treaty but because the statute goes into effect without further congressional action, while the treaty may, and, in many instances, does, require such assistance."

${ }^{5}$ Cook v. United States, 288 U.S. ro2, 53 Sup. Ct. 305, 77 L.Ed. 64I (1933).

52 The importance of this case is stressed by Butler in his remarks found in the American Society International Law, Proceedings (1929), 176-180. 
they conflicted with treaties. On the contrary, the Supreme Court has, in practically every instance, upheld the treaties and declared conflicting state laws inapplicable..$^{53}$

State courts ordinarily decide in favor of state laws and not treaties when the two appear to be in conflict. In a few instances the Supreme Court of the United States has affirmed such decisions, as in the case of Rocca v. Thompson..$^{54}$ Nevertheless there are some state cases which have upheld treaties, ${ }^{55}$ and when this happens it is very unusual for the Supreme Court, on appeal, to reverse the opinion of the state court and reconcile the state statute with the treaty. Yet that was the ruling in Todok $v$. Union State Bank $k^{56}$ where the Supreme Court of the State of Nebraska had held a state law inapplicable on the ground that it was in conflict with a treaty between the United States and Norway. ${ }^{57}$ On appeal to the Supreme Court, Chief Justice Hughes held that the law of Nebraska should not be construed to be inapplicable since it did not conflict with the treaty. Among all the Supreme Court cases this seems to be the only one in which the Court has ever interpreted a state law more liberally than a treaty when the two were in apparent conflict. But this fact should not be overemphasized because in construing and upholding the law the Court at least rendered a decision in harmony with the purpose of the treaty.

It may therefore be said that the Supreme Court throughout its history has consistently upheld treaty provisions which were in direct conflict with state laws. This attitude of the Court naturally conforms to the supremacy clause of the Constitution in so far as treaties are concerned, and thus it is a principle of constitutional interpretation that state laws conflicting with existing treaties are inapplicable and rights granted by the treaties shall prevail. However, there are certain exceptions implied in some of the decisions of the Court; for instance, a treaty that is clearly in conflict with public policy or with rights clearly within the power of the states will not be held applicable..$^{58}$ Thus, a treaty will not usually be con-

53 Shanks v. Dupont, 3 Pet. (U.S.) 242, 7 L.Ed. 666 ( $183^{\circ}$ ); Ware v. Hylton, supra note 5; Hauenstein v. Lynham, 100 U.S. 483, 25 L.Ed. 628 (I879).

54 Rocca v. Thompson, 223 U.S. $3^{17} 7,32$ Sup. Ct. $207,5^{6}$ L.Ed. 453 (Igr2).

55 In the case of Jordan v. Tashiro, 278 U.S. I23, 49 Sup. Ct. 47,73 L.Ed. 214 (I928), the Supreme Court affirmed a state court decision upholding a treaty provision alleged to be in conflict with state laws.

${ }^{56}$ Todok v. Union State Bank, 28x U.S. 449, 50 Sup. Ct. 363, 74 L.Ed. $95^{6}$ (I930).

57 Engen v. Union State Bank, 118 Neb. 105, 223 N.W. 664 (I929). 8 Stat. 60, 64 ( 1783 ); 8 Stat. 232, 234 (1816); 8 Stat. 346,354 (1827).

58 "But if we attempted to use the treaty-making power to deal with matters which did not pertain to our external relations but to control matters which normally and appropriately were within the local jurisdiction of the States, then I again say there might be ground for im- 
strued as prevailing over rights vested in a state unless it expressly divests the states of these rights.

This concludes our study of the position of treaties in the constitutional system of the United States. The results of our investigation may be briefly summarized as follows: As a general principle, the express constitutional requirements place limitations on treaty-making, but these are the only constitutional limitations thus far recognized. It is probable that in cases of alleged conflict between treaties and acts of Congress, both of which form part of the supreme law of the United States, the Supreme Court has shown a bias in favor of the latter. Nevertheless when a treaty conflicts with an earlier statute the Court will uphold the treaty. ${ }^{99}$ Moreover, in one case the Court held the treaty-power to extend further than the enumerated legislative powers of Congress. ${ }^{60}$ State laws, and ordinances issued under state law, if in conflict with provisions in treaties, must yield to the treaties and are inapplicable when conflicting with rights arising from a treaty. The only exceptions are treaties in conflict with public policy or with rights clearly within the powers of the states. Thus treaties occupy the same general position as do congressional statutes; and, as law, treaties are to be applied by the courts in deciding any controversy as to private rights derived from treaties.

The Court applies treaties equally with other forms of national law, without passing directly upon questions involving the international obligations of the United States. ${ }^{6 x}$ Nevertheless, it has said on occasion that no ruling made on treaties could in any way relieve the nation of its international responsibility, but that the question of international obligation was a matter for the determination of the political branches of the government. ${ }^{62}$ Thus the Court has indicated that any modification of a treaty would be a proper subject matter for negotiation between the parties and that the Court's decision would apply only to the questions arising under the treaty.

If rights vested under the treaty depend on the purpose of the parties; which, however, is in doubt, the Supreme Court may consider matters in

plying a limitation upon the treaty-making power that it is intended for the purpose of having treaties made relating to foreign affairs and not to make laws for the people of the United States in their internal concerns through the exercise of the asserted treaty-making power." Charles E. Hughes, Proceedings, supra note 45 . See, Rocca v. Thompson, supra note 54 .

59 See Cook v. United States, supra note 5 I.

${ }^{60}$ Missouri v. Holland, sucpra note 40.

${ }^{6 x}$ Supra note 47 . Cf. also Devlin, supra note 6, 94, §94.

${ }_{62}$ Statements to this effect were made in Whitney v. Robertson, supra note 46; Head Money Cases, supra note 46; Factor v. Laubenheimer, supra note I, I96. 
connection with the negotiation of the treaty, in an endeavor to determine the true construction. ${ }^{63}$ In a number of cases the Court gave a great deal of attention to evidence indicating the policy of the President and the State Department either at the time the treaty was signed or in subsequent years. ${ }^{64}$ Any evidence of intention or policy such as the travaux preparatoires ${ }^{65}$ may indicate the purpose of the parties, but the Court is not necessarily bound by this evidence. A number of cases have been decided in which the Court looked not only to the preparatory work but also to later diplomatic correspondence between the parties as evidence of their purpose, and in so doing was guided by the attitude of the political departments. ${ }^{66}$

There have been a number of cases arising from the various treaties of cession by which the United States has on several occasions acquired territory from other nations. It was said, in United States v. Arredondo ${ }^{67}$ that a treaty of cession was a "deed of the ceded territory, the sovereign is the grantor, the act is his, so far as it relates to the cession, the treaty is his act and deed, and all courts must so consider it." Although the cases arising under these treaties may be of importance, it is not our purpose to study them in detail, but only as they are illustrative of other topics under discussion. Most of these cases arose under the treaty with Spain and the United States signed in $18 \mathrm{rg}$ and ratified in $182 \mathrm{r} .^{68}$ In nearly all of them the Court followed the policy and action of the political departments. ${ }^{69}$

There is another large group of cases that will not receive much consideration in this study, namely, treaties with the Indian tribes which have been of some importance in the history of our country, $7^{70}$ but which

${ }_{63}$ Cf. Terrace v. Thompson, 263 U.S. $x_{97}, 44$ Sup. Ct. I5, 68 L.Ed. 255 (r923); Rocca v. Thompson, 223 U.S. 317,32 Sup. Ct. 207, 56 L.Ed. 453 (IgI2); Kinkead v. United States, 150 U.S. 483,5 II, I4 Sup. Ct. I72, 37 L.Ed. II 52 (1893); United States v. Texas, I62 U.S. I, I6 Sup. Ct. 725, $4 \circ$ L.Ed. 867 (1896); Cook v. United States, supra note $5 \mathrm{x}$; Factor v. Laubenheimer, supra note I.

${ }_{64}$ The Court attached much weight to the views of the State Department, expressed some years after the treaty between the United States and Japan, of Igrr, had entered into force. Terrace v. Thompson, supra note 63 .

${ }_{5}$ Cook v. United States, supra note $5 \mathrm{I}$; also see Miller, R. W., Preparatory Work in the Interpretation of Treaties, I7 Iowa L. Rev., 366, 373 (1932); Chang, The Interpretation of Treaties by Judicial Tribunals (I933), I3I-r40.

${ }^{66}$ Terrace $\mathrm{v}$. Thompson, supra note 63 .

${ }_{7}$ United States v. Arredondo, 6 Pet. (U.S.) 69r, 738, 8 L.Ed. 738 (1832).

${ }^{68}$ Crandall, supra note $14,569-574$.

${ }^{69}$ United States v. Percheman, 7 Pet. (U.S.) 5I, 8 L.Ed. 604 (I833); cf. Crandall, stcpra note 68 .

$7^{70}$ Since $187 \mathrm{I}$, pursuant to congressional legislation then enacted, no treaties are made with Indian tribes. ${ }_{5}$ Stat. 7 (I867). Cf. 2 Butler, supra note I4, c. I4. 
by their very nature differ from treaties between independent nations. ${ }^{7 r}$ Although in theory an Indian treaty after proclamation by the President is as much law as any other treaty, in practice the Supreme Court has consistently recognized a difference in the two types of treaties both as to the nature of the compact as well as in the manner of construction. ${ }^{72}$ There may be some question whether these are treaties in an international sense, but it can not be doubted that they are treaties in our system of law. For our purpose these treaties and cases arising under them will not be considered as treaties, as the term is used in international law.

Since it is the function of the Supreme Court to decide questions involving private rights arising under a treaty it results that the Court must interpret or place constructions upon treaty provisions that are in litigation. These constructions, taken as a whole, constitute the principal contribution made by the Supreme Court to this phase of international law. It is an elementary rule that the Court will never place any interpretation on a law unless there is a bona fide dispute concerning the rights involved, and this fact is especially true in so far as treaties are concerned. Cases appear on the Supreme Court docket either for review from the highest state courts and from the lower federal courts or by reason of the original jurisdiction of the Court.

The Supreme Court, in these cases, is applying an international compact as part of the municipal law to litigations involving private rights under national law. ${ }^{73}$ This constitutes the full extent of the Court's power, and thus it happens that the task of interpretation comprises the principal work of the Supreme Court on treaties. ${ }^{74}$ The Court has ordinarily employed the two terms interpretation and construction to mean the same thing; since this is true, they will be employed here in the same manner. ${ }^{75}$ The formulation of certain constructions usually results from any of a number of causes; that is, some constructions may be the result of a policy formulated for that particular case, some may be the result of previous decisions, while others may be reached because of being in accord with "public policy." 76 The Supreme Court may claim it is conforming to a liberal or broad construction, although exactly what is meant by these

$7 x$ Jones v. Meehan, I75 U.S. I, 20 Sup. Ct. I, 44 L.Ed. 49 (I899).

${ }^{72}$ Ibid.

${ }_{73}$ Cf. Scott, The Legal Nature of International Law, i Am. Jour. Int. L. 83I-866 (I907); and Willoughby, The Legal Nature of International Law, 2 Am. Jour. Int. L. 357-365 (I908).

${ }_{74} \mathrm{Cf}$. Tennant, The Judicial Process of Treaty Interpretation in the United States Supreme Court, 30 Mich. L. Rev. ror6-1045 (1932).

75 Cf. Goetze v. United States, I03 Fed. 72 (S.D.N.Y. I900); and Devlin, supra note 6, § Ix5. ${ }^{6} \mathrm{Cf} .2$ Butler, supra note I4, $3^{6} 3^{-6} 4, \S 46 \mathrm{r}$. 
terms may be difficult to understand from a study of the cases. ${ }^{77}$ It may be a liberal construction if the case is decided in favor of those whose rights are acquired by the contract, that is, the nationals of the other party to the treaty, and this results in a narrow construction with respect to the rights of American citizens..$^{78}$ To uphold a contention of liberality one must define that term, yet in the decisions of the Supreme Court it is neither clearly explained nor defined. One may look to see what general principles or rules have been formulated by the Court. ${ }^{79}$

In construing treaty provisions the Court has regarded treaties as international compacts to be faithfully observed by the United States. Any other view would have made it difficult for the United States to meet its international obligations. The tendency is for the Supreme Court to construe treaties in the highest good faith in so far as the other party is concerned, a principle of construction which the Court has consistently asserted. It was said by Justice Brown in Tucker v. Alexandroff ${ }^{80}$ that the particular convention in question was operative upon both parties "and intended for their mutual protection," and therefore that the treaty "should be interpreted in a spirit of uberrima fides, and in a manner to carry out its manifest purpose." There are hardly any exceptions to this principle of the Court. Since the United States is only one party to a treaty and the treaty appears on the statute books, the Supreme Court is really determining rights arising under municipal law; but has in almost every decision, in so far as its power of interpretation is concerned, looked to and upheld the principle of "good faith." $8 x$.

There may be certain exceptions to the above rule. For example, as has been pointed out above, when there is a conflict between a treaty and a later act of Congress then the Court follows the legislative branch of the government. With this exception it has been the policy of the Court to construe treaties as binding instruments, and even in those cases in which acts of Congress have been applied over conflicting treaties the decisions did not relieve the United States of its international obligation, a fact which has been readily admitted by the Court. ${ }^{82}$

77 Chang, The Interpretation of Treaties by Judicial Tribunals (1933), c. I.

${ }^{8} \mathrm{Ibid}$., I85; Hyde, C. C., Interpretation of Treaties by the Supreme Court, 23 Am. Jour. Int. L. $824-828$ (I929).

79 In Goetze v. United States, supra note 75, it was thought that construction had a broader meaning than interpretation, but there is no indication that this view has prevailed among Supreme Court justices.

${ }^{80}$ Tucker v. Alexandroff, 183 U.S. 424, 437, 22 Sup. Ct. 195, 46 I.Ed. 264 (Igo2).

8x Head Money Cases, supra note 46, 598. Fuller, C. J., said, "It (the treaty) depends for the enforcement of its provisions on the interest and the honor of the governments which are parties to it." Cf. Tennant, supra note 74, 1038-1039.

${ }^{82}$ Supra note 47. 
Another principle of the construction of treaties which is often considered in international law is that a vital change in circumstances justifies the renunciation of a treaty. It may be a matter of dispute whether under the prevalent system of law the Court would apply the doctrine. It appears that the Supreme Court has never held a treaty provision inapplicable on the ground that circumstances had vitally changed since the negotiation of the treaty. ${ }^{83}$ Indeed, it is rather unlikely that the Court in practice would adopt the doctrine of rebus sic stantibus, and declare a treaty unenforceable for this reason. The principles involved in questions of the effect of war on treaties are somewhat analogous to this doctrine. However, there is a difference in these two phases of treaty interpretation. ${ }^{84}$ In this case study, the principle of rebus sic stantibus may be passed over, for there have been no cases before the Supreme Court directly involving the doctrine and further discussion would be mere speculation. ${ }^{85}$

There is a special "so-called" rule of construction that merits consideration at this point, namely, the rule of liberal interpretation. It is often said that the Supreme Court applies the fundamental principle that treaties should receive a liberal interpretation to give effect to their apparent purpose. This was the assertion of Justice Brown in Tucker $v$. Alexandroff (I902). ${ }^{86} \mathrm{If}$, however, there is a rule of liberal construction, as he infers, the significant question arises as to what is meant by the term "liberal." To attempt an answer to this question it is important to trace the history of the "rule." It was perhaps in the embryonic stage of development in 1796 when it was first stated as dictum by Justice Patterson in the case of Ware v. Bylton. ${ }^{87}$

In that case the statement was made that treaties should be construed liberally. Justice Patterson claimed that, "The construction of a treaty made in favor of such creditors, and for the restoration and enforcement of pre-existing contracts, ought to be liberal and benign." 88 This comment was mere dictum; certainly it had no bearing on the case and could hardly be considered a rule laid down by the Supreme Court. A few years after Ware o. Hyltion, the liberality "rule" appeared in the form of a

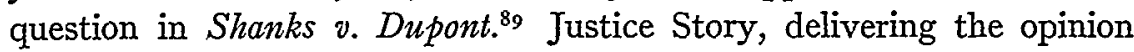

\footnotetext{
${ }_{83}$ Pergler, C., Judicial Interpretation of International Law in the United States (I928), I80.

${ }^{8} 4$ Cf. Karnuth v. United States, 279 U.S. 23I, 244, 49 Sup. Ct. 274, 73 L.Ed. 677 (1929).

85 Cf. Hooper v. United States, 22 Ct. Cl. 408,464 (r887).

${ }^{86}$ I 83 U.S. 424, 437, 22 Sup. Ct. 195, 46 L.Ed. 264 (rgo2).

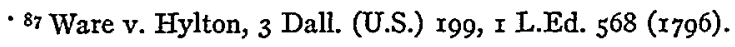

${ }^{88}$ Ibid., 256.

${ }^{89}$ Shanks v. Dupont, 3 Pet. (U.S.) 242, 7 L.Ed. 666 (r830).
} 
of the Court, said, "If the treaty admits of two interpretations, and one is limited, and the other liberal; one which will further, and the other exclude private rights; why should not the liberal exposition be adopted"?9o The implication, of course, is that Justice Story approved the rule, but it is apparent from an analysis of the case that the rule, presented as a question, was not the basis of the decision. The treaty might have been more narrowly construed, it is admitted, but it is questioned whether the Court actually set down a rule of liberality and followed it, for the case was decided on other principles of law.

Justice Swayne said, in Hauenstein v. Lynham, that the rule of liberal construction was "the settled rule in this court,"9r and cited the case of Shanks v. Dupont..$^{92}$ It would appear that if Justice Swayne meant by this statement that Justice Story had applied the rule in Shanks v. Dupont he undoubtedly erred. Moreover, it is questioned whether Justice Swayne himself applied the "rule" in Hauenstein v. Lynham, although he rendered lip-service to it as a doctrine of law. ${ }^{93}$ In that case the Court interpreted the treaty according to its obvious meaning, and so far as the decision was concerned, there was no need for the assertion made by Justice Swayne.

Justice Field, in Geofroy $v$. Riggs, ${ }^{94}$ again asserted the principle that treaties should receive a liberal construction. He inferred that this was the principle followed in In re Ross, ${ }^{95}$ and in the dissent in Kinkead $v$. United States. ${ }^{96}$ But in Geofroy 0. Riggs the treaty was not interpreted in the light of the liberal interpretation "rule," for the Court decided the case in accordance with the intention and purposes of the contracting parties, and also upon the principle of "good faith." Apparently the alleged rule might have been omitted and the same conclusion reached, consequently its statement may be considered as dictum. It is also questionable whether the Court really applied the rule in the case of In re Ross.97

${ }^{90}$ Ibid., 249.

9: Hauenstein v. Lynham, 100 U.S. 483, 487, 25 L.Ed. 628 (I879).

${ }^{2}$ Supra note 89 .

93 Supra note gr.

94 Geofroy v. Riggs, I33 U.S. $258,27 x$, ro Sup. Ct. 295, 33 L.Ed. 642 (I89o).

95 In re Ross, I40 U.S. 453 , II Sup. Ct. 897,35 L.Ed. 58 I (I89I).

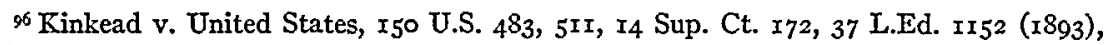
Shiras, J. dissenting, "But when we consider that we are dealing with an international instrument, transferring territorial dominion from one sovereign to another, a broader and more liberal construction should be put on the language used. Hauenstein v. Lynham, Io U.S. $48_{3}$; Head Money Cases, II2 U.S. 580."

${ }_{97}$ Cf. also Factor v. Laubenheimer, supra note I, $195-196$, Stone, J., "In choosing between conflicting interpretations of a treaty obligation, a narrow and restricted construction is to be avoided as not consonant with the principles deemed controlling in the interpretation of inter- 
Has there ever been a Supreme Court case in which the statement of the rule was other than dictum?. Possibly Tucker v. Alexandroff,,${ }^{88}$ and Jordan v. Tashiro ${ }^{99}$ are such cases. In the former case there may be some merit in the contention that Justice Brown did actually apply the liberal construction principles, which, through frequent assertion by the Court, even by way of dicta in the earlier cases had now become established as a rule of treaty construction. At the same time, however, Justice Brown brings in other principles by claiming that a treaty should always be interpreted in the highest good faith and that it is necessary to look to the practice of nations and the intention of the parties. Moreover, in Tucker $v$. Alexandroff it is questioned whether the Court could not have reached the same conclusion without reverting to the "rule" of liberal construction. In fact, the strong dissenting opinion must carry much weight. ${ }^{\mathbf{x} 0}$

In Neilson v. Johnson ${ }^{\text {Ior }}$ the Supreme Court did not accept or follow the liberal construction theory, but examined the preparatory work for evidence as to what was the proper interpretation of the treaty. Nor have the Supreme Court justices always rendered lip service to the liberal construction principle. If Tucker v. Alexandroff and Jordan v. Tashiro be excepted, it may be doubted whether there is any case in which the principle is laid down as binding. The Court has certainly applied the rule that treaties should be construed in the best of faith in so far as the other party to the treaty is concerned, but this is not the same thing as applying a rule of liberal construction; that is, deciding treaty provisions broadly in the interest of those whose rights accrue as a result of the action of the other party or in favor of the other party signing the treaty. ${ }^{\mathbf{1 0 2}}$

In Terrace v. Thompson ${ }^{\mathrm{ro3}}$ the Court, in reaching its decision, accepted as conclusive evidence the correspondence between Secretary of State Bryan

national agreements. Considerations which should govern the diplomatic relations between nations, and the good faith of treaties, as well, require that their obligations should be liberally construed so as to effect the apparent intention of the parties to secure equality and reciprocity between them. For this reason if a treaty fairly admits of two constructions, one restricting the rights which may be claimed under it, and the other enlarging it, the more liberal construction is to be preferred."

${ }^{8}$ Supra note 7.

${ }^{99}$ Jordan v. Tashiro, 278 U.S. $x 23,49$ Sup Ct. 47,73 L.Ed. 2 I $_{4}$ (r928).

${ }^{100}$ See note criticising the majority opinion, 15 Harv. L. Rev. $657-658$ (I902). Gray, J., Fuller, C. J., Harlan and White, J. J., dissented in Tucker v. Alexandroff.

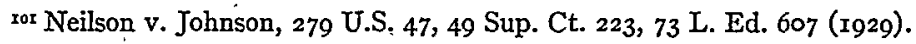

${ }^{102} \mathrm{Cf}$. Westlake, Int. Law (rg04), 282-283, Pt. I. He mentions two forms of interpretation. One of these he claims to be a broader principle of construction and he cites as an example, Whitney v. Robertson, I $24_{4}$ U.S. r9o, 8 Sup. Ct. 456 , 3 I L.Ed. 386 (I888).

${ }^{103}$ Terrace v. Thompson, 263 U.S. I97, 224, 44 Sup. Ct. 15, 68 L.Ed. 255 (I923). 
and the Japanese Ambassador. Although this correspondence took place some years after the treaty was signed, it was thought to indicate clearly the intention of the parties. The doctrine of liberal construction was stated as a principle of interpretation in Factor v. Laubenheimer, ${ }^{\mathrm{T} 04}$ but it is doubtful whether the Court will even refer to the principle if the treaty provision in question is clear and not ambiguous. The alleged rule was entirely ignored in Rocca v. Thompson, ${ }^{\text {105 }}$ perhaps due to the fact that any application of a liberal construction rule or a hint of following such a rule would have meant reaching an entirely different conclusion. As a matter of fact, in this case the Court applied a narrow construction of the treaty.

By way of summary, the conclusion is reached that there is no rule of liberal construction binding upon the Court, so that it must be applied in all cases involving the interpretation of a treaty; nor can the other principles of treaty construction, which the Court has from time to time asserted, be considered in the light of binding rules. For example, Factor $v$. Laubenheimer, ${ }^{106}$ the most recent case in which the interpretation of a treaty was involved, states with approval practically all of the principles of treaty construction contained in earlier decisions, and discussed above. "If a treaty fairly admits of two constructions, one restricting the rights which may be claimed under it, and the other enlarging it, the more liberal construction is to be preferred ..... Considerations which should govern .... the good faith of treaties .... require that their obligations should be liberally construed so as to effect the apparent intention of the parties. ... . In ascertaining the meaning of a treaty we may look beyond its written words to the negotiations and diplomatic correspondence of the contracting parties relating to the subject matter. . . . In resolving doubts the construction of a treaty by the political department, while not conclusive upon courts called upon to construe it, is nevertheless of weight."

It is suggested, however, that these principles were not a controlling factor in determining the conclusion of the Court, but, rather, were brought in as supporting arguments to show the correctness of the conclusion. Thus, after deciding that the right of extradition existed only by treaty, the Court turned to the pertinent treaty provisions. It found that the offense charged was contained only in the supplementary extradition treaty of 1889 , which provided that "certain offenses, those enumerated in the classes numbered 4 and Io, and in the unnumbered class" were

so4 Supra note I.

${ }^{105}$ Rocca v. Thompson, 223 U.S. 317,32 Sup. Ct. 207,56 L.Ed. 453 (IgI2).

rob Supra note I, ro6.

ro7 Ibid. 
extraditable only if "made criminal" or "punishable" by the laws of both countries. But the crime with which Factor was charged did not fall within these classes, and hence, according to the Court, was not subject to the limitations quoted above. This "distinction, appearing on the face of the convention," seems to have been the controlling factor in the decision. In other words, the Court examined the treaty, decided the case and then showed that its conclusion was in harmony with the various principles of treaty interpretation which it has asserted in previous cases.

The source of these principles cannot be precisely nor authoritatively determined. There is good ground for arguing that the Court drew them from commonly accepted principles of customary international law, at least to a large extent. This is borne out by the fact that in many of the decisions citations to eminent international law authorities may be found, and because from its earliest history the Supreme Court has considered itself bound "to receive the law of nations in its modern state of purity and refinement." "ro8

${ }^{208}$ Ware v. Hylton, 3 Dall. (U.S.) I99, 281, I L.Ed. 568 (I796). 